Original Articles

\title{
Sustainability indicators for improved assessment of the effects of agricultural policy across the EU: Is FADN the answer?
}

\author{
Edel Kelly ${ }^{\mathrm{a}, *}$, Laure Latruffe ${ }^{\mathrm{b}}$, Yann Desjeux ${ }^{\mathrm{b}}$, Mary Ryan ${ }^{\mathrm{c}}$, Sandra Uthes ${ }^{\mathrm{d}}$, Ambre Diazabakana ${ }^{\mathrm{b}, \mathrm{e}}$, \\ Emma Dillon ${ }^{\mathrm{c}}$, John Finn ${ }^{\mathrm{f}}$ \\ ${ }^{a}$ School of Agriculture \& Food Science, University College Dublin, Belfield, Dublin 4, Ireland \\ b INRA, SMART-LERECO, Rennes, France \\ ${ }^{\mathrm{c}}$ Teagasc, Rural Economy \& Development Programme, Athenry, Co. Galway Ireland \\ ${ }^{\mathrm{d}}$ Leibniz Centre for Agricultural Landscape Research (ZALF), Muencheberg, Germany \\ e Vertigo Lab, Bordeaux, France \\ ${ }^{\mathrm{f}}$ Teagasc, Crops Environment and Land Use Programme, Johnstown Castle, Co Wexford, Ireland
}

\section{A R T I C L E I N F O}

\section{Keywords:}

Sustainability

Indicators

European union

Farm accountancy data network

Rural development programme

\begin{abstract}
A B S T R A C T
Policy reform of the CAP and society's expectations of agriculture have resulted in a growing need for improved information on the effectiveness of policy in achieving high-level objectives for more sustainable practice in agriculture. This is a high priority given its importance for consumers, public policy and private industry. Data collection programmes will need to adapt their scope if their information is to adequately address new information needs about high-level objectives. Assessment of sustainability at the farm level is hindered by the lack of data with which to derive appropriate, meaningful, and relevant indicators. This is particularly problematic for assessment of agricultural sustainability across the European Union (EU). Various databases exist at the EU scale regarding agricultural data sources and we identify one of these, the EU Farm Accountancy Data Network (FADN), as having considerable potential to assess farm-level sustainability at EU level. We critique several examples of published work that has attempted to assess agricultural sustainability using: FADN data alone; FADN data in combination with data from supplementary surveys, and; FADN data in combination with data from other EU databases. We conclude that the FADN would need to broaden its scope of data collection if it is to address the new information needs of policy, and we discuss the challenges in expanding FADN with a view towards wider farm-level assessment of sustainability. These include careful selection of indicators based on various criteria, the representativeness of the FADN, and the need to include new themes to address environmental, social, and animal welfare effects of policy.
\end{abstract}

\section{Introduction}

Global demands for finite resources have prompted governments to increasingly promote sustainable choices and actions in society. However, to meet these global demands, agricultural food production must increase, thus the impact of the sustainable intensification of agriculture and natural resource usage on the environment is central to any debate on sustainability (Teillard et al., 2016). However, there has been considerable variation in terms of how sustainability in agriculture is defined (Latruffe et al., 2016a,b; Hayati, 2017). Viewed from the perspective of the farm, the contribution to sustainable agriculture encompasses the production of goods and services (economic dimension), the management of natural resources (ecological dimension) and the contribution to rural communities (social dimension). Movement towards sustainability will necessarily involve simultaneous progress along these interconnected dimensions.

There is also variability in how sustainability is pursued in the policy-making process (Binder et al., 2010). For example, the European Commission has included three priorities in its Europe 2020 strategy, one of them being 'Sustainable growth: promoting a more resource efficient, greener and more competitive economy' (European Commission, 2010a) and also recognises that agriculture delivers 'multiple economic, social, environmental and territorial benefits' (European Commission, 2010b). These priorities are reflected in changing policies which seek to encourage the provision of environmental and social benefits from agriculture in rural areas, through agri-environment schemes (AESs) and

\footnotetext{
* Corresponding author. Postal address: 1.22 Agri-Business and Rural Development, School of Agriculture \& Food Science, University College Dublin (UCD), Belfield, Dublin 4, Ireland.

E-mail addresses: edel.kelly@ucd.ie (E. Kelly), laure.latruffe@inra.fr (L. Latruffe), yann.desjeux@inra.fr (Y. Desjeux), mary.ryan@teagasc.ie (M. Ryan), uthes@zalf.de (S. Uthes), ambrediazabakana@vertigolab.eu (A. Diazabakana), emma.dillon@teagasc.ie (E. Dillon), john.finn@teagasc.ie (J. Finn).
} 
more recently, through European Innovation Partnerships (EIPs). As policies broaden so too must policy evaluation, taking into account not only the provision of food (market) goods and the impact on the environment and natural resources, but also the more intangible (public) goods delivered by agricultural food production, such as rural vitality and the maintenance of rural heritage and traditions (Cooper et al., 2009).

Sustainability can be assessed at different scales, such as global, local, sector-specific, individual (farm or household) and site-specific (e.g. plot). In agriculture, assessment of sustainability at the farm level is common (e.g. see the international initiative 'Sustainability Assessment of Food and Agriculture systems' by the Food and Agriculture Organisation (FAO) (FAO, 2013a, 2013b), for several reasons. Firstly, the individual (farm) level is the most important spatial unit in terms of the implementation of sustainable actions, as farmers operate at this scale and management decisions can be directly influenced through interventions for improved implementation. Secondly, although indicators of sustainability can be developed at various levels including regional and national levels, the farm-level approach increases the spatial accuracy of indicators, which is highlighted as a main challenge (Burkhard et al., 2009). Finally, the farm is the legal unit for legislative purposes and the economic unit that generally receives payments for externalities, and as such is the level at which most policies are directed (OECD, 2001).

In general, farm-level assessments of sustainability are carried out at a small scale within a specific case study setting (e.g. de Koeijer et al., 2002; Dolman et al., 2012; Mollenhorst et al., 2006; Moreno-Pires and Fidélis, 2012; Thivierge et al., 2014; Zahm et al., 2008), and therefore findings may not always be generalizable to wider scales. This is particularly problematic in meeting high-level data needs to evaluate policy questions across the European Union (EU). Although several databases currently provide agricultural data at the EU scale, the challenge associated with measuring the economic, environmental and social dimensions of sustainability is the availability of data that reflect all three dimensions, while also being robust and representative across Member States (MS) to enable cross-country assessments of EU policies.

This paper suggests that one data source, namely the EU Farm Accountancy Data Network (FADN), has considerable potential to assess farm-level sustainability across all three dimensions on an EU-wide basis. The aim of the paper is two-fold: to show that the FADN is already widely used to assess farm-level sustainability (with limitations) and to demonstrate that although the FADN is primarily oriented towards economic issues, it offers (with modifications) an appropriate platform to represent many of the economic, environmental and social dimensions of agricultural sustainability, while also facilitating EU-scale assessment. First, we set the general context for this study before focusing on FADN as a data collection mechanism for agricultural production in the EU. Through some examples, we then examine the current potential of FADN data to assess farm-level sustainability. The limitations and the challenges afforded by FADN for a broader assessment of sustainability are discussed and conclusions are drawn.

\section{Rationale and background}

\subsection{Usefulness of farm-level sustainability indicators}

Sustainability in agriculture can be considered as a prerequisite for transition to sustainable development at the global level. The application of the concept of sustainable development in agriculture raises interest in both the sustainability of the agricultural system itself and its contribution to sustainable development (Bockstaller et al., 2009). It thus incorporates the principal dimensions and objectives of sustainability when sustainable practices are implemented on a given agricultural system (Schaller, 1993; den Biggelaar and Suvedi, 2000; Gafsi et al., 2006). In assessing sustainability, the individual farm is considered the most appropriate spatial unit in terms of the implementation of sustainable farm activities. This is reinforced by the Common Monitoring and Evaluation Framework (CMEF) for the 2007-2013 Rural Development Programme (RDP), which provides guidance on various common indicators and a single framework for monitoring and evaluating all rural interventions across EU MS (European Commission 2003, 2015; Uthes et al., 2017) and recommends data collection at an individual (i.e. farm) level (European Commission, 2010c).

In relation to their usefulness, farm-level sustainability indicators can be used to monitor farm activities to assist in decision-making and assess progress towards more sustainable farming (Vilain, 1997) and decision support and sustainability assessment tools based on indicators have been developed by researchers and private value-chain stakeholders (e.g. Murphy et al., 2013; de Olde et al., 2016). These indicators can be used to improve the understanding of the relationship between the environmental, economic and societal impacts of agricultural activities.

Sustainability indicators are also useful in comparing farm performance and benchmarking across farms. Previous research has proven the effectiveness of benchmarking (the process of identifying, learning from and adapting better practices from other farmers) in improving farm performance, efficiency, sustainability and profitability (Kahan, 2013; Kragten and de Snoo, 2003). Sustainable value methods which provide scores to farms are common and can be used to set targets, but functional units can also be used to compare farms (Lebacq et al., 2013), for example the expression of environmental impacts, such as emissions per product (Hennessy et al., 2013) or emissions on a per hectare basis (Buckley et al., 2016).

Sustainability indicators are also widely used for policy design and evaluation (both public and private policies) and for meeting industry quality standards (by individual farms) at different scales of implementation. Indeed, linkages that exist between policies, agriculture and the environment are complex, and vary across countries and policy contexts. Policy makers require appropriate and relevant indicators to evaluate ex-ante policy scenarios, to design/improve (new) policy measures and to evaluate policy instruments.

At the EU level, the Common Agricultural Policy (CAP) is one of the only policies for which periodic evaluations are required by the European Commission. Since its inception in the 1960s, the CAP has undergone several reforms. The 1999 reform ('Agenda 2000') split the policy into two different pillars as policy measures devoted to agricultural production were gathered under Pillar I, while rural development was dealt with under Pillar II through the RDP (European Commission, 2003). The 2003 (Luxembourg) reform introduced three compulsory RDP evaluations per 7-year programming period (i.e. exante, mid-term, and ex-post evaluations), with a consequent increase in the demand for suitable data and relevant indicators.

To summarise, the CAP has evolved greatly, particularly over the last 10-15 years, with the primary focus moving from increasing agricultural productivity through market and income stabilisation, to objectives that include viable food production, the sustainable use of natural resources, mitigation of climate change and balanced territorial development. The most recent CAP (2013) reform specifically addressed commitments to economic, social and environmental sustainability with the RDP oriented towards improved competitiveness of agriculture, sustainable management of natural resources and climate action, and a balanced territorial development of rural areas (ENRD, 2015). The goal is 'no longer simply to maximise productivity but to optimise across a far more complex landscape of production, rural development, environmental, social justice and food consumption outcomes' (Pretty et al., 2010). Given increasing reporting requirements for policy planning, implementation, evaluation and impact assessment, existing monitoring and data collection systems must also evolve to take account of new policy topics such as risk stabilization funding as well as information on plant health and animal welfare. Thus, MS are confronted with new measurement and evaluation needs which are 
Table 1

Objective-related baseline indicators of the CMEF: data availability for different administrative levels (reporting year 2013).

Source: the authors, based on EUROSTAT 2013.

\begin{tabular}{|c|c|c|c|c|c|}
\hline Indicator & Baseline lead indicator & $\begin{array}{l}\text { Country } \\
(\mathrm{N}=27)\end{array}$ & $\begin{array}{l}\text { Regional level NUTS1 } \\
(\mathrm{N}=97)\end{array}$ & $\begin{array}{l}\text { Regional level NUTS2 } \\
(\mathrm{N}=270)\end{array}$ & $\begin{array}{l}\text { Regional level NUTS3 } \\
(\mathrm{N}=1290)\end{array}$ \\
\hline \multirow[t]{13}{*}{ 1-Socio-economic indicators } & Economic development & $100 \%$ & $94.8 \%$ & $92.2 \%$ & $91.8 \%$ \\
\hline & Employment rate & $100 \%$ & $100 \%$ & $100 \%$ & $0 \%$ \\
\hline & Unemployment & $100 \%$ & $100 \%$ & $100 \%$ & $0 \%$ \\
\hline & Economic development in primary sector & $96.3 \%$ & $93.8 \%$ & $91.9 \%$ & $91.6 \%$ \\
\hline & $\begin{array}{l}\text { Importance of semi-subsistence farming in new } \\
\text { Member States }\end{array}$ & $100 \%$ & $99.0 \%$ & $84.8 \%$ & $0 \%$ \\
\hline & Economic development of food industry & $100 \%$ & $0 \%$ & $0 \%$ & $0 \%$ \\
\hline & $\begin{array}{l}\text { Economic development of non-agricultural } \\
\text { sector }\end{array}$ & $100 \%$ & $94.8 \%$ & $92.2 \%$ & $91.8 \%$ \\
\hline & Self-employment development & $100 \%$ & $100 \%$ & $100 \%$ & $0 \%$ \\
\hline & Internet take-up in rural areas & $92.6 \%$ & $0 \%$ & $0 \%$ & $0 \%$ \\
\hline & Development of services sector & $100 \%$ & $94.8 \%$ & $92.2 \%$ & $91.8 \%$ \\
\hline & Net migration & $100 \%$ & $100.0 \%$ & $99.3 \%$ & $99.2 \%$ \\
\hline & Life-long learning in rural areas & $100 \%$ & $99.0 \%$ & $98.5 \%$ & $0 \%$ \\
\hline & Development of Local Action Groups & $88.9 \%$ & $0 \%$ & $0 \%$ & $0 \%$ \\
\hline \multirow[t]{14}{*}{ 2-Sectoral indicators } & Training and education in agriculture & $100 \%$ & $100 \%$ & $85.2 \%$ & $0 \%$ \\
\hline & Age structure in agriculture & $100 \%$ & $99.0 \%$ & $84.8 \%$ & $0 \%$ \\
\hline & Labour productivity in agriculture & $100 \%$ & $0 \%$ & $0 \%$ & $0 \%$ \\
\hline & Gross fixed capital formation in agriculture & $88.9 \%$ & $49.5 \%$ & $41.1 \%$ & $0 \%$ \\
\hline & Employment development of primary sector & $100 \%$ & $93.8 \%$ & $90.7 \%$ & $91.5 \%$ \\
\hline & Labour productivity in forestry & $77.8 \%$ & $0 \%$ & $0 \%$ & $0 \%$ \\
\hline & Gross fixed capital formation in forestry & $48.1 \%$ & $0 \%$ & $0 \%$ & $0 \%$ \\
\hline & Labour productivity in food industry & $85.2 \%$ & $0 \%$ & $0 \%$ & $0 \%$ \\
\hline & Gross fixed capital formation in food industry & $55.6 \%$ & $0 \%$ & $0 \%$ & $0 \%$ \\
\hline & Employment development in food industry & $55.6 \%$ & $99.0 \%$ & $98.1 \%$ & $0 \%$ \\
\hline & Organic farming & $100 \%$ & $100 \%$ & $85.2 \%$ & $0 \%$ \\
\hline & Farmers with other gainful activity & $100 \%$ & $100 \%$ & $99.3 \%$ & $67.8 \%$ \\
\hline & $\begin{array}{l}\text { Employment development of non-agricultural } \\
\text { sector }\end{array}$ & $100 \%$ & $93.8 \%$ & $90.7 \%$ & $91.5 \%$ \\
\hline & Tourism infrastructure in rural areas & $100 \%$ & $95.9 \%$ & $95.9 \%$ & $0 \%$ \\
\hline \multirow[t]{9}{*}{ 3-Environment indicators } & Biodiversity: Population of farmland birds & $22.2 \%$ & $0 \%$ & $0 \%$ & $0 \%$ \\
\hline & $\begin{array}{l}\text { Biodiversity: High Nature Value farmland and } \\
\text { forestry }\end{array}$ & $96.3 \%$ & $13.4 \%$ & $79.6 \%$ & $0 \%$ \\
\hline & Biodiversity: Tree species composition & $92.6 \%$ & $0 \%$ & $0 \%$ & $0 \%$ \\
\hline & Water quality: Gross Nutrient Balances & $100 \%$ & $0 \%$ & $0 \%$ & $0 \%$ \\
\hline & $\begin{array}{l}\text { Water quality: Pollution by nitrates and } \\
\text { pesticides }\end{array}$ & $48.1 \%$ & $0 \%$ & $0 \%$ & $0 \%$ \\
\hline & Soil: Areas at risk of soil erosion & $88.9 \%$ & $89.7 \%$ & $91.1 \%$ & $95.1 \%$ \\
\hline & $\begin{array}{l}\text { Climate change: Production of renewable } \\
\text { energy from agriculture and forestry }\end{array}$ & $92.6 \%$ & $0 \%$ & $0 \%$ & $0 \%$ \\
\hline & $\begin{array}{l}\text { Climate change: utilised agricultural area (UAA) } \\
\text { devoted to renewable energy }\end{array}$ & $100 \%$ & $0 \%$ & $0 \%$ & $0 \%$ \\
\hline & $\begin{array}{l}\text { Climate change/air quality: gas emissions from } \\
\text { agriculture }\end{array}$ & $100 \%$ & $0 \%$ & $0 \%$ & $0 \%$ \\
\hline
\end{tabular}

constrained by the availability of appropriate farm-level data.

Finally, there is an increasing importance placed on consumer confidence in food supply and on consumer demands and expectations of food producers and systems regarding food safety, quality and sustainability. The provision of information on the sustainability of the agri-food sector is therefore fundamental in meeting such demands, while the production of sustainable food itself is increasingly becoming an important international marketing tool (e.g. the Origin Green initiative by Bord Bia in Ireland).

\subsection{Databases of farm-level data collected at the EU scale}

Although various databases provide agricultural information at the EU level, few have the potential to simultaneously assess sustainability across its dimensions. The Eurostat database contains information from which some of the CMEF indicators are derived to track the integration of environmental concerns in the CAP. However, they are provided at sub-regional levels but are not available for all EU regions. As an illustration, Table 1, gives an indication of the level of coverage across MS and regions for each of the CMEF indicators. For example, the indicator 'Farmers with other gainful activity' has a value of $67.8 \%$ at the NUTS3 level, indicating that 874 regions out of the total 1290 NUTS3 regions in the EU have provided a value for this indicator. For 'biodiversity', there are no data that reflect populations of farmland birds and tree species at regional level. Similarly, there are no data currently available at sub-national level for 'water quality' (which reflects nutrient balances and pollution through pesticides and nitrates), or for 'climate change' (which reflects production of renewable energy and emissions from agriculture).

However Eurostat data are not available at farm level. Those datasets that are collected consistently at farm level throughout the EU on a yearly basis include:

- the IACS (Integrated Administration and Control System database, which manages CAP payments to farmers;

- the Land Parcel Identification System (LPIS) spatial database, which is part of IACS and monitors land parcels and land use at farm level; and

- the FADN database.

Although these databases were not designed to assess farm-level sustainability, they have common observations and can thus be integrated. For example, each farm in the IACS database has corresponding observations in LPIS, while each FADN farm receiving CAP 
payments can be matched to IACS and LPIS observations). Another useful feature of IACS is the inclusion of data on direct payment support schemes and rural development measures, including cross-compliance provisions relating to farm holdings and registration of animals. The LPIS database is based on ortho-photographs of land parcels eligible for payments under IACS. It also contains data on land use and soil landscape elements at parcel level, and each farm is directly linked with IACS through farm identification numbers. The LPIS database thus has potential to assess landscape elements or some (limited) environmental indicators (Desjeux et al., 2015).

There are some limitations, however. For example, the IACS and its associated database LPIS, were designed as an administrative tool for monitoring CAP payments to farmers. Consequently, data are only available for farms that are, or have been, in receipt of CAP payments. In addition, when considered as separate databases, the LPIS and IACS offer little potential in terms of measuring farm-level sustainability because of the lack of data on economic and social dimensions of sustainability. However, there is potential to provide agricultural sustainability assessments by merging these administrative datasets with other farm-level datasets (e.g. the economic data in the FADN).

In summary, there is a lack of appropriate farm-level data for the assessment of agricultural sustainability in IACS, LPIS and Eurostat databases. Although LPIS and IACS are farm-level databases, they contain insufficient information to calculate sustainability indicators, and while Eurostat contains a more appropriate range of indicator types, it lacks a detailed breakdown at the farm level. In contrast, the FADN database is a more promising source for measuring sustainability, given that it collects data annually across a range of indicators at farm level. Another consideration is that temporal assessment of trends in sustainability indicators is becoming increasingly important. Thus, from the perspective of developing common indicators at the European scale, FADN is a good starting point as farm-level data collection has been ongoing in some MS for over 40 years. For these reasons, we focus on FADN in the following text.

\subsection{The farm accountancy data network}

Farm accountancy data are collected on a yearly basis by each MS for a sample of EU farms in a harmonised manner to provide a homogeneous EU database. Currently, the annual sample which contains around 1000 variables covers approximately 80,000 farms, representing a population of about $5,000.000$ farms in the EU and about $90 \%$ of the total agricultural production. The selection methodology of FADN farms aims to provide representative data along three dimensions: region, economic size and type of farming, resulting in standardised aggregate data collected across the EU (European Commission, 2010d). However, FADN is limited to coverage of agricultural holdings considered as commercial, a classification based on size (a farm which is large enough to provide a main activity for the farmer and a level of income sufficient to support his/her family), and thus is not representative of all smaller farms. Further information on FADN is provided in Appendix A.

In addition to the provision of an EU wide annual database of microdata (farm level), a key strength of FADN is that it provides a harmonised platform for the collection of directly comparable farm statistics by MS (Hennessy and Kinsella, 2013) which is supported by a rigorous data management, testing and validation infrastructure. Thus, the use of FADN data overcomes difficulties generally encountered in cross-country comparisons, which include the heterogeneity of farm systems, differences in exchange rates, accounting methods, definitions of technical terms, and guarantees the coherence and homogeneity necessary for this type of approach. In addition, owing to the longitudinal nature of the data, FADN can be used to analyse and forecast retrospective and future trends, while providing a robust basis for collecting sustainability information and measuring farm-level sustainability.
The information which is legally required by the European Commission which we denote as 'core FADN' consists largely of economic farm data. This limitation has been overcome in some MS by the collection of additional, more detailed data beyond the legal requirement. Such data are however only available within the relevant national FADN databases and are not provided to the European Commission. Bradley and Hill (2015), report that such additional data are routinely collected in many MS. For example, Ireland and the Netherlands collect additional data that allow for the calculation of greenhouse gas (GHG) emissions and nitrogen (N) balances. The Hungarian database also includes details on nutrient balances. Such data are invoice-based and consequently fit well with FADN accountancy protocols. However, non-invoice-based data are also collected. For example, information about innovation on farms is collected in the Netherlands, while a few social indicators, such as living alone or not, are available in Ireland. Through the French FADN, additional data are available on energy use of fuel, gas and electricity. In the United Kingdom (UK), information on off-farm employment is recorded.

\section{Analyses of current uses of FADN data for assessment of farm- level sustainability}

This section presents some examples of national case studies that illustrate how FADN can be used to assess farm-level sustainability, as a stand-alone database or in conjunction with other data sources. The selected studies do not represent an exhaustive list but rather illustrate how the network of FADN farms has been leveraged to support research on sustainability. We distinguish between the studies based on data sources utilised (Table 2):

- Type 1-a: case studies that utilise data from EU FADN (denoted as (core FADN').

- Type 1-b: case studies that utilise data from core FADN in combination with national initiatives which collect additional data through the FADN nationally. These are collected at the level of individual MS with no EU co-ordination of data collection ('supplementary FADN').

- Type 2: case studies that utilise data from FADN (whether core or supplementary), in combination with additional data from sources other than FADN, available at national, EU or international level ('hybrid FADN').

\subsection{Assessment of sustainability with core FADN only}

A review of studies relying on core FADN data reveals that these studies generally only assess the economic dimension of sustainability, as this is the basis of the core FADN. For example, Latruffe and Desjeux (2016) used FADN data to study the effect of various CAP payments (investment, production and rural development payments) on the change in technical efficiency and productivity on specialist tillage and livestock farms from 1990 to 2006. Similarly, Kleinhanß et al. (2007) investigated the effect of CAP environmental payments on efficiency and environmentally friendly behaviour. While these studies would not have been possible without core FADN data, it is not possible to look beyond the economic dimension of sustainability using only core FADN data.

\subsection{Assessment of sustainability with supplementary FADN (core FADN supplemented with national FADN data)}

Beyond core FADN data requirements, many national initiatives use the FADN platform to collect additional supplementary data. From a data quality perspective, the added-value for MS is two-fold. First, the supplementary data collection meets the standards associated with collection of core FADN data. Second, the existing FADN infrastructure facilitates efficient data collection and management practices including 
Table 2

Selected studies that use FADN data for assessment of farm-level sustainability.

\begin{tabular}{|c|c|c|c|}
\hline Sustainability themes [application] & Literature reference & $\begin{array}{l}\text { Country studied and type of FADN [(a): } \\
\text { core FADN; (b): national FADN] }\end{array}$ & Sources of additional data \\
\hline \multicolumn{4}{|l|}{ Type 1-a: Core FADN } \\
\hline Economic [technical efficiency] & Latruffe and Desjeux (2016) & (a) France & \\
\hline $\begin{array}{l}\text { Environment [environmental } \\
\quad \text { payments] }\end{array}$ & Kleinhanß et al. (2007) & (a) Germany/Europe & \\
\hline \multicolumn{4}{|l|}{ Type 1-b: Supplementary FADN } \\
\hline Economic, Environment & Ehrmann (2008) & (b) Germany & \\
\hline Economic, Environment & Ehrmann (2010) & (b) Germany & \\
\hline Economic, Environment, Social & Cadilhon et al. (2006) & (b) France & \\
\hline Economic, Environment, Social & Dillon et al. (2010) & (b) Ireland & \\
\hline Economic, Environment, Social & Dolman et al. (2014) & (b) Netherlands & \\
\hline $\begin{array}{l}\text { Economic, Environment, Social, } \\
\text { Innovation }\end{array}$ & $\begin{array}{l}\text { Dillon et al. (2016); Hennessy et al. (2013); Lynch et al. } \\
\text { (2016); Ryan et al. (2014); Ryan et al. (2015); Ryan et al. } \\
\text { (2016) }\end{array}$ & (b) Ireland & \\
\hline Environment [intensification] & Barnes and Thomson (2014) & (b) Scotland & \\
\hline Environment [nutrient balance] & Pesti and Keszthelyi (2009) & (b) Hungary & \\
\hline Environment $[G H G]$ & Samson et al. (2012) & (b) France & \\
\hline Environment [habitats] & Sheridan et al. (2011) & (b) Ireland & \\
\hline \multicolumn{4}{|l|}{ Type 2: Hybrid FADN } \\
\hline Economic [competitiveness] & Thorne and Fingleton (2006); Gillespie and Thorne (2016) & (a) Europe & $\begin{array}{l}\text { International Farm Comparisons } \\
\text { Network (IFCN) }\end{array}$ \\
\hline Economic [performance] & Latruffe and Piet (2014) & (b) France & LPIS \\
\hline Economic [subsidy dependence] & Latruffe and Mann (2015); Delame et al. (2015) & (b) France & Tax records \\
\hline Economic, Environment, Social & Batalla et al. (2014) & (b) Northern Spain & Experts and stakeholders \\
\hline Environment [nutrient balance] & Buckley et al. (2015); Buckley et al. (2016) & (b) Ireland & National database \\
\hline Environment $[\mathrm{AE}$ footprint index] & Westbury et al. (2011) & (b) United Kingdom & National database \\
\hline Innovation [farm practices] & Läpple et al. (2015) & (b) Ireland & Experts \\
\hline
\end{tabular}

the establishment of trusting relationships with farm holdings. Here we describe several studies that used such data to go beyond the assessment of just economic sustainability.

For example, Dolman et al. (2014) benchmarked the performance of Dutch dairy farms using supplementary data from the Minerals Policy Monitoring Programme, collected through the Dutch FADN, based on economic, environmental and societal performance of dairy farms. Farms aiming to improve their internal nutrient cycle were compared to other dairy farms using 15 individual environmental indicators and three economic indicators. Social sustainability indicators included: payments for agri-environmental measures (euros/ha), penalties for aberrant milk composition (\% of milk) as a proxy for food safety, and grazing (hours/cow) as a proxy for animal welfare.

The Irish FADN has evolved in response to various policy changes at EU level by collecting supplementary data across the environmental, social and innovation dimensions to create a bank of farm-level sustainability indicators. Six selected studies used these supplementary data to provide benchmarks of current sustainability trends in Irish farming. The novel indicators developed include social assessment of vulnerability and isolation (Dillon et al., 2010; Hennessy et al., 2013; Lynch et al., 2016) and environmental assessment such as GHG emissions on a per product basis (Hennessy et al., 2013; Ryan et al., 2014; Dillon et al., 2016). The richness of this data source and the longitudinal availability of these data allow for the assessment of trends in farm sustainability over time (Hennessy et al., 2013; Ryan et al., 2016).

Ehrmann (2008) collected supplementary data and compared three different assessment methods for sustainability at farm level in 4000 dairy farms of the German FADN. Economic indicators included income per annual working unit (AWU), profit ratio, remuneration of factors, net debt service, change of owner's equity both per ha and per AWU, net investment per AWU, and farm net value added per ha. Ecological indicators included nutrient balances, soil organic matter balance, pesticide use, crop diversity and median field size. A further study (Ehrmann, 2010) assessed the economic and ecological impacts of different policy scenarios, namely environmental policy measures (fertiliser taxes and restrictions), direct payments and variation of input and output prices.
Some studies have focus specifically on the environment. For instance, Sheridan et al. (2011) conducted farmland habitat surveys on 50 grassland farms that were participating in the Irish FADN, while Pesti and Keszthelyi (2009) assessed the environmental sustainability of Hungarian FADN farms from 2003 to 2007 based on various indicators (nutrient balances and proportion of organic manure in the nutrient supply).

These cases further highlight the level of detail which is lacking in the core FADN data for the proper assessment of farm-level sustainability. They also provide examples of how MS have conducted supplementary data collection to build on the existing FADN data, and used novel methods to investigate farm-level sustainability.

\subsection{Assessment of sustainability with hybrid FADN (FADN in combination with additional datasets)}

In this section, we describe studies that merged national FADN databases (whether core FADN or supplementary national FADN) with another (non-FADN) database. For example, Delame et al. (2015) and Latruffe and Mann (2015) used national FADN data matched with French tax records to provide information on household incomes (including farm and off-farm incomes), that would not be possible using FADN data alone. Another French study undertook the extension and adaptation of the sustainability indicators in the IDEA ('Indicateurs de Durabilité des Exploitations Agricoles') method to assess the sustainability of the main French types of farming. The set of indicators of the IDEA method were combined with information from the French FADN and Agricultural Census to develop the IDERICA method (Zahm et al., 2008; Cadilhon et al., 2006). Generally used in specific and limited case studies, the IDEA methodology assigns sustainability scores using 41 sustainability indicators relating to economic, environmental and social aspects (Vilain, 2008). For a set of 50 farms, Cadilhon et al. (2006) compared both sets of indicators, i.e. the original full set of IDEA indicators and the adapted set of indicators from the merged database of FADN and Agricultural Census. The study concluded that many of the original IDEA indicators could not be calculated and that the most problematic issue was the assessment of social sustainability. 
Another French analysis undertaken by Latruffe and Piet (2014) utilised a combination of national supplementary FADN and LPIS data. This analysis assessed the link between farmland fragmentation (available from LPIS) and farm economic performance (available from French FADN). In contrast to the merging of the FADN and French tax records undertaken by Latruffe and Mann (2015), it was not possible to merge these databases as they are both anonymised. Hence, the authors first calculated average farmland fragmentation in each municipality from individual LPIS data, and then used these data to explain individual farm performance proxied by various indicators calculated from FADN.

Additionally, some studies relied on external information such as specific coefficients or metrics. For example, Westbury et al. (2011) used a combination of the UK FADN and the Agri-Environmental Footprint Index methodology to derive weighted indicators of environmental performance of different farming systems and regions, or used information on the total expenditure on fertiliser and standard fertiliser costs to derive quantities of fertiliser used on farms.

National FADN data are also sometimes enriched by supplementary data from international databases. For example, Buckley et al. (2015) and Buckley et al. (2016) computed nutrient balances per product in Ireland using the national FADN database and international standard coefficients. Also, international economic competitiveness comparatives were made between EU FADN countries and the International Farm Comparisons Network (IFCN) through merging existing data, as for example in Thorne and Fingleton (2006) and Gillespie and Thorne (2016). Examples of studies that used expert opinions to complement core FADN or supplementary national FADN are Batalla et al. (2014) who utilised this method to inform indicator definition and Läpple et al. (2015) who utilised these data to apply weighting in generating a farm innovation index.

\subsection{Alternatives to FADN}

While there are obvious benefits to using FADN infrastructure as a basis for further developing sustainability assessments, there are also challenges involved in this approach. Therefore, we briefly consider alternative approaches to the expansion of the FADN database. The challenges associated with reconciling observations from different datasets could be alleviated by the enrichment of existing EU datasets, although this could be costly and as we have already seen, the resolution of other EU datasets may not be sufficient to collect data at the farm level. Another approach to augmenting data sources could be the establishment of a new network of farms on which tailored economic, environmental and social data would be collected. However, this would require a comprehensive cost-benefit analysis and constitute a significant duplication of FADN data collection and management and require considerable investment. Beyond the financial costs, skilled data collectors are required and costly data management and testing infrastructures would need to be developed to achieve the robust standards inherent in the FADN reporting structures. Thus, we do not consider this approach further here.

\section{Discussion}

Although not exhaustive, the above overview shows that the FADN infrastructure and database offer considerable potential for the assessment of agricultural sustainability. It also shows that the use of core FADN on its own, generally only allows for the assessment of the economic dimension. However, when core FADN data are combined with other data (supplementary FADN and/or hybrid FADN) the holistic assessment of farm-scale sustainability is greatly enhanced. Possibly the key strength of FADN is that the existing platform for the collection of farm statistics across the EU on a yearly basis already facilitates comparison analyses across MS. As such, it is the only source of microeconomic data that is harmonised across the $\mathrm{EU}$, and hence provides a strong opportunity to expand the data collection to provide broader coverage of the dimensions of sustainability to answer new and emerging policy questions. However, there are several challenges which would need to be addressed in expanding FADN to meet new data requirements to assess broader aspects of farm-level sustainability.

\subsection{Additional FADN data required for sustainability assessment}

Although FADN is a rich source of economic data, the changing policy environment means that there are data gaps in relation to the evaluation of new economic policies such as risk management strategies. In addition, while FADN reports comprehensively on farm incomes, the incidence and/or level of off-farm income are not reported; thus, analysis of overall household income is currently not possible across EU MS. According to Eurostat, 'an income measure which aims to be a proxy for the standard of living of the agricultural community ... will need to cover income from all sources, not just from farming activity' (Eurostat, 1995). In a sector where the incidence of off-farm employment is so high, and the impact of that off-farm income is so significant (O'Donoghue et al., 2016), the farm income measure in isolation can paint an inaccurate picture about the true economic status of farm families. Despite this, the overarching objective of FADN has been, and continues to be, to collect data on output, input and income in relation to the farm rather than the farm household. However, this is an important area in relation to the consideration of additional FADN data collection. Interestingly, information on off-farm revenue is available in the FADN-like database for Switzerland, while in Ireland, the incidence (but not the level) of off-farm income is reported in the national supplementary FADN, allowing for greater depth of analysis of farm household viability (Hennessy and Moran, 2015).

The core FADN lacks sufficient environmental data to address environmental sustainability at farm level. For instance, the costs (verified by invoices) of potential pollutants (e.g. chemical inputs, products contributing to GHG emissions) rather than the quantities of these materials are recorded, preventing the accurate assessment of the environmental impact of farms. Few countries currently collect sufficient supplementary FADN data to compute GHG emissions and $\mathrm{N}$ balance (based on invoices and international coefficients). Through specific methods such as multicriteria analysis (MCA) or Life Cycle Assessment (LCA), further information would have to be collected to assess the environmental impacts of agricultural production systems. Some studies have carried out LCA using FADN data in specific countries such as the Netherlands (Thomassen et al., 2009) and Switzerland (Jan et al., 2012). However, the EU FADN legislation is evolving in response to changing policy needs and MS are required to include quantities of fertiliser minerals in their core FADN dataset by 2019. This is a significant first step but additional information is still required for a range of production processes that are environmentally relevant (e.g. pesticides, concentrate feed, manure and slurry management and animal weights). The core FADN also lacks information on soil (e.g. quality, organic matter, erodibility) and water quality/availability, along with activity data to assess issues around climate change (mitigation and adaptation).

The inclusion of farm-level biodiversity assessments of agricultural sustainability presents many challenges (Hennessy et al., 2013) but is a dimension of environmental sustainability that is rapidly growing in importance. Information on Ecological Focus Areas (EFAs) has recently been integrated in the LPIS to help monitor the Greening of payments in Pillar 1 of the 2014-2020 CAP. This could be linked to FADN by merging procedures; however, this information alone is not sufficient to address biodiversity issues at farm level, and would need to be complemented by supplementary surveys of farmland biodiversity, farm ecosystems management, landscape metrics, and (semi-)natural habitats, (see Appendix B, as well as Sheridan et al. (2011) and Sullivan et al. (2013) for examples).

The social dimension represents another information gap whether 
using core FADN alone or in conjunction with additional data. Social themes are difficult to assess without collecting additional data on the farm and social information on the farm/farmer may be sensitive. In addition, the validity of subjective social indicators may be questionable as these are estimations or perceptions where memory errors or individual characteristics are highly influential in comparison with the evidence (invoice-based) data currently collected for FADN. Nevertheless, farmers' decisions are not driven only by profit-maximisation but also by non-pecuniary issues that include social and lifestyle benefits (Howley, 2015) and addressing these social issues at farm level is a necessity to accurately assess farm sustainability. In addition, the social dimension of agricultural sustainability includes the impact of agriculture beyond the farm gate, i.e. societal effects. These impacts can include, for example, provision of direct and indirect employment in rural areas and the contribution to rural areas' vitality, and would require information on farms' interactions with the local economy such as purchasing and spending patterns (Lobley et al., 2009; Roberts et al., 2013). The protection of animal welfare is another social theme that concerns society as a whole, and could be assessed through information on, e.g., housing and feeding systems, animals' morbidity and mortality rates (von Keyserlingk et al., 2009).

\subsection{Extending the scope of FADN}

FADN data provide robust information on farm agricultural production, farm accountancy, farm economic performance, and farm structures issues. However, expanding the scope of FADN to incorporate non-economic information may necessitate data collector upskilling and/or specialist expertise on data collection in disciplines not traditionally represented in FADN (e.g. ecologists, environmental scientists, sociologists). Alternatively, the farm-scale collection of such specialised data could also be outsourced to external appropriate companies with specialist skills.

Any expansion of the scope of FADN would be a significant undertaking and would require a clear definition of farm-level indicators of sustainability, especially for environmental and social sustainability. We have mentioned several themes and indicators of economic, environmental and social dimensions of agricultural sustainability (e.g. risk management, off-farm income, GHG emissions, biodiversity, soil organic matter, farmers' lifestyle benefits, contribution to rural employment, animal welfare). Some further examples of the range of new policy topics, information needs, and potential indicators are provided in Appendix B (see also Latruffe et al. (2016a,b) and Herrera et al. (2016). Due to budgetary and technical limits, any expansion of the FADN database would however require ex ante decision-making on the choice of the sustainability themes covered, the selection and/or design of appropriate indicators, as well as a decision on the boundaries of assessment (farm household, farm as a legal entity, beyond the farm gate etc.). This may entail a public consultation of what the society considers as important needs and challenges (e.g. the European Commission's public consultation in the CAP in ECORYS, 2017), the involvement of experts and agricultural stakeholders to solicit opinion (e.g. van Calker et al., 2005; Herrera et al., 2016; de Olde et al., 2017), and ex post analyses of sustainability on existing data (e.g. van Passel et al., 2007; Latruffe et al., 2016a,b). The choices would also be guided by the trade-off between the value of the information conveyed by a proposed indicator and the costs of collecting the necessary information.

\subsection{Assessment across the heterogeneity of european conditions}

Designers of data collection processes are usually challenged to adapt existing methods to their needs and national contexts (in addition to EU requirements), and to develop methods to address different farming systems and context heterogeneity as the policy usefulness of indicators must be judged within the specific context in which they are assessed. For example, the restriction imposed under the EU Nitrates directive sets a limit for nitrogen application at $170 \mathrm{~kg} / \mathrm{ha}$, which is $80 \%$ higher than the usual application rate in Hungary. Additionally, while water availability and consumption (e.g. for irrigation purposes) is an issue in some countries (e.g. Spain, Greece) it might not be an issue in other countries (e.g. Finland, UK). Similarly, pesticide use is less problematic in countries where livestock farming is dominant (e.g. Ireland), than in crop-growing countries/regions. If the objective is to collect data to inform EU-wide progress on sustainability, then careful thought must be given to the selection of indicators that represent common standardised assessments that are universally applicable.

Collecting additional data places an increased burden on data collectors and farmers, and hence a balance must be achieved which will meet additional needs and not create unnecessary burdens. From this perspective, the harmonised nature of the FADN data offers considerable potential to build on and learn from existing common approaches across MS. In addition, the extension of the existing FADN infrastructure to accommodate more information relevant to new policy questions affords opportunities to broaden the expertise base of all MS in relation to sustainability assessments through the sharing of expertise across current national supplementary FADN analyses that go beyond core FADN.

\subsection{Representativeness of FADN}

FADN provides information to the EU on economic and productivity issues at farm level and is designed to be representative of $90 \%$ of all agricultural output above a given value threshold and is therefore oriented towards commercial farms (see Appendix A). While FADN contains information on some small farms, many of these are part-time farms that are only viable due to CAP payments and/or off-farm employment, yet these holdings may be important in terms of the local economy based on their input requirements, and their contribution to the production of externalities (positive and negative). Also, farms and farming systems associated with Natura 2000 and High Nature Value (HNV) farming areas are likely to be under-represented in FADN (Green et al., 2015). Similarly, social issues (such as rural poverty) may be under-reported if FADN alone is used as a source of data.

The nature of the information required by the EU has changed radically, particularly as revisions of the CAP have moved from payments coupled to agricultural production, to payments which incentivise and reward the provision of environmental and social public goods. CAP funding now extends well beyond the sample of farmers represented by FADN, yet there is very limited data to assess policy effectiveness in farm systems not covered by FADN. In the case of an enrichment of FADN with additional sustainability data, the sample selection plan should be considered to ensure that the diversity of multi-functional agriculture in the EU is represented.

However, the question of representativeness depends on the objective behind the collection of additional FADN information. If the objective is to evaluate the effectiveness and efficiency of the policy measures through a better understanding of farmers' behaviour and the choices that they make in trade-offs between economic, social and (sometimes contradictory) environmental goals, then complementing existing economic information with environmental and social information is necessary to fulfil this objective. By contrast, if the objective is to assess the environmental or social sustainability of all EU farmers, including those outside the definition of 'commercial farms' (notably small or extensive farms), then a specific sample could be selected to be representative of the environmental or social themes considered.

\subsection{Frequency of data collection}

Although many economic indicators can be recorded on a yearly basis due to available accountancy data, indicators relating to other 
themes (such as greenhouse gases, quality of life, product marketing or non-agricultural income) require data that are less commonly recorded as a matter of routine. Therefore, the frequency of data collection could vary according to the type of data. Some indicators may not need to be collected every year. For example, soil organic matter content, or farmland habitat structure are unlikely to experience great volatility over time, and for such indicators, data could be collected in a less frequent but regular supplementary survey to the core FADN.

\subsection{Data protection}

Personal information (e.g. revealing plans for succession or inheritance, working conditions or off-farm income) may be of a sensitive nature and this must be considered when selecting indicators and collecting data. Confidentiality and data protection are increasingly important in light of the 2018 regulation relating to the processing of personal data (Regulation EU ${ }^{\circ} 2016 / 679$ ). This may pose legal challenges for the collection, processing and transfer of personal information as part of the current FADN database, but will also provide challenges for additional data collection (direct collection or through the merging of databases). Data management protocols will need to fully comply with the relevant EU regulation and safeguard the rights of farmers from whom information is collected. These challenges would no doubt be even greater without the personal relationships and trust already built between farmers and FADN data collectors.

\section{Conclusions}

A combination of policy reform of the CAP and changes in the societal expectations of agriculture have resulted in a growing need for improved information on the effectiveness of policy in achieving highlevel objectives for more sustainable agriculture. Such information will only be derived from evaluation of data from monitoring programmes, and this inevitably challenges monitoring programmes to adapt their scope if their information is inadequate to assess high-level objectives. Currently, there is a lack of appropriate farm-level data for the assessment of agricultural sustainability from the information currently available from European-scale databases (e.g. IACS, LPIS and Eurostat). We identify the FADN as having considerable potential to provide robust answers to complex emerging policy questions, largely due to its harmonised governance structure across Member States. Current efforts to use FADN data only highlight the inadequacy of FADN to address several prominent themes of the RDP, especially the environmental and social themes (as well as others). The use of FADN data in combination with other data (whether they are collected in complementary surveys or through integration with other databases) illustrates the considerable potential of FADN to provide robust answers to complex emerging policy questions. Unlocking this potential will require careful selection and design of new indicators to expand the scope of data collection by the FADN to meet new information needs.

\section{Acknowledgements}

This work was partly funded by the FLINT project under the EU Seventh Framework Programme grant number 613800. The opinions expressed in this paper are not necessarily those of the EU.

\section{Appendix A. Supplementary data}

Supplementary data associated with this article can be found, in the online version, at https://doi.org/10.1016/j.ecolind.2017.12.053.

\section{References}

Barnes, A.P., Thomson, S.G., 2014. Measuring progress towards sustainable intensification: how far can secondary data go? Ecol. Indic. 36, 213-220.
Batalla, M.L., Pinto, M., del Hierro, O., 2014. Environmental, social and economic aptitudes for sustainable viability of sheep farming systems in northern Spain. In: 11th European IFSA Symposium: Farming Systems Facing Global Challenges: Capacities and Strategies Proceedings. Berlin, Germany, 1-4 April, International Farming Systems Association (IFSA) Europe, Leibniz-Centre for Agricultural Landscape Research (ZALF) Humboldt-Universität zu Berlin. pp. 1493-1502.

Binder, C.R., Feola, G., Steinberger, J.K., 2010. Considering the normative, systemic and procedural dimensions in indicator-based sustainability assessments in agriculture. Environ. Impact Assess. Rev. 30 (2), 71-81.

Bockstaller, C., Guichard, L., Keichinger, O., Girardin, P., Galan, M.-B., Gaillard, G., 2009. Comparison of methods to assess the sustainability of agricultural systems. A review. Agron. Sustain. Dev. 29 (1), 223-235.

Bradley, D., Hill, B., 2015. Cost of and Good Practices for FADN Data Collection - Final Report. Directorate General for Agriculture and Rural Development, European Commission, Brussels, Belgium.

Buckley, C., Wall, D., Moran, B., Murphy, P., 2015. Developing the EU Farm Accountancy Data Network to derive indicators around the sustainable use of nitrogen and phosphorus at farm level. Nutr. Cycl. Agroecosyst. 102, 319-333.

Buckley, C., Wall, D., Moran, B., O’Neill, S., Murphy, P., 2016. Farm gate level nitrogen balance and use efficiency changes post implementation of the EU Nitrates Directive. Nutr. Cycl. Agroecosyst. 104, 1-13.

Burkhard, B., Kroll, F., Müller, F., Windhorst, W., 2009. Landscapes' capacities to provide ecosystem services - a concept for land-cover based assessments. Landsc. Online 15, $1-22$.

Cadilhon, J.J., Bossard, P., Viaux, P., Girardin, P., Mouchet, C., Vilain, L., 2006. Caractérisation et suivi de la durabilité des exploitations agricoles françaises: les indicateurs de la méthode IDERICA. Notes et Etudes Economiques 26, 127-158.

Cooper, T., Hart, K., Baldock, D., 2009. Provision of Public Goods through Agriculture in the European Union. Report Prepared for Directorate General Agriculture and Rural Development. Institute for European Environmental Policy, London, UK (Contract No 30-CE-0233091/00-28).

Delame, N., Butault, J.-P., Pollet, P., 2015. L'allocation du travail des ménages agricoles entre travail agricole, activités de diversification et emplois extérieurs: une première approche à partir du raccordement RA-RICA-déclarations fiscales de 2010. In: Paper Presented in SFER Seminar. Rennes, France, February 12-13.

Desjeux, Y., Dupraz, P., Kuhlman, T., Paracchini, M.L., Michels, R., Maigné, E., Reinhard, S., 2015. Evaluating the impact of rural development measures on nature value indicators at different spatial levels: application to France and the Netherlands. Ecol. Indic. 59, 41-61.

Dillon, E.J., Hennessy, T., Hynes, S., 2010. Assessing the sustainability of Irish agriculture. Int. J. Agric. Sustain. 8 (3), 131-147.

Dillon, E.J., Hennessy, T., Buckley, C., Donnellan, T., Hanrahan, K., Moran, B., Ryan, M., 2016. Measuring progress in agricultural sustainability to support policy-making. Int. J. Agric. Sustain. 14 (1), 31-44.

Dolman, M.A., Vrolijk, H.C.J., de Boer, I.J.M., 2012. Exploring variation in economic, environmental and societal performance among Dutch fattening pig farms. Livest. Sci. 149 (2), 143-154.

Dolman, M.A., Sonneveld, M.P.W., Mollenhorst, H., de Boer, I.J.M., 2014. Benchmarking the economic, environmental and societal performance of Dutch dairy farms at internal recycling of nutrients. J. Clean. Prod. 73, 245-252.

ECORYS, 2017. Modernising and simplifying the CAP - summary of the results of the public consultation. Report for the European Commission-DG Agri, Brussels, 7 July. URL: https://ec.europa.eu/agriculture/sites/agriculture/files/consultations/capmodernising/summary-public-consul.pdf (Accessed 17 November 2017).

ENRD, 2015. Rural Development Priorities 2014-2020. Projects Brochure, The European Agricultural Fund for Rural Development. European Network for Rural Development (ENRD)(URL: https://enrd.ec.europa.eu/sites/enrd/files/uploaded-files/publi-enrdbrochure01-2015.pdf (Accessed 17 November 2017).

Ehrmann, M., 2008. Comparing sustainable value approach, data envelopment analysis and indicator approaches - an application on german dairy farms. In: Paper Presented at the 12th Congress of the European Association of Agricultural Economists (EAAE). Ghent, Belgium.

Ehrmann, M., 2010. Assessing ecological and economic impacts of policy scenarios on farm level. In: Paper Presented at the 50 st Annual Conference of the German Association of Agricultural Economists (GEWISOLA). Braunschweig, Germany, September 29-October 1.

Commission, European, 2003. Rural Development in the European Union - Fact Sheet. Directorate General for Agriculture and Rural Development, Brussels, Belgium.

European Commission, 2010a. A strategy for smart, sustainable and inclusive growth. Communication from the Commission: Europe 2020, Brussels, Belgium, COM (2010) 2020 Final. (34p).

European Commission, 2010b. The CAP Towards 2020: Meeting the Food, Natural Resources and Territorial Challenges of the Future. Communication from the Commission to the European Parliament, the Council, the European Economic and Social Committee and the Committee of the Regions. Brussels, Belgium COM (2010) 672 final, 15p.

European Commission, 2010c. The CMEF Gross Value added indicators Working Paper. Directorate General for Agriculture and Rural Development, Brussels, Belgium 23p.

European Commission, 2010d. Farm Accounting Data Network An A to Z of methodology, Version 04/11/2010. URL http://ec.europa.eu/agriculture/rica/pdf/site_en.pdf (Accessed 17 November 2017).

European Commission, 2015. Technical Handbook on the Monitoring and Evaluation Framework of the Common Agricultural Policy 2014-2020. Directorate General for Agriculture and Rural Development, Brussels, Belgium.

Eurostat, 1995. Total Income of Agricultural Households. (Luxemburg).

FAO, 2013a. SAFA - Sustainability Assessment of Food and Agriculture Systems - 
Guidelines. Version 3.0. Natural Resources Management and Environment Department, Food and Agriculture Organisation (FAO), Rome, Italy (December 267p).

FAO, 2013b. SAFA - Sustainability Assessment of Food and Agriculture Systems Indicators. Natural Resources Management and Environment Department, Food and Agriculture Organisation (FAO), Rome, Italy (281p).

Gafsi, M., Legagneux, B., Nguyen, G., Robin, P., 2006. Towards sustainable farming systems: effectiveness and deficiency of the French procedure of sustainable agriculture. Agric. Syst. 90 (1-3), 226-242.

Gillespie, P., Thorne, F., 2016. Review of the competitiveness of the Irish Dairy Sector at Farm Level. In: Presentation at Teagasc Outlook Economic Prospects for Agriculture. November 29, RDS Dublin Ireland.

Green, S., O'Donoghue, C., Moran, B., 2015. Assessing the geographic representativity of farm accountancy data: opportunities for new FADN changes. In: Paper Presented in the 150th Seminar of the European Association of Agricultural Economists (EAAE). October 22-23, Edinburgh, Scotland, UK.

Hayati, D., 2017. A Literature Review on Frameworks and Methods for Measuring and Monitoring Sustainable Agriculture. Technical Report n.22. Global Strategy Technical Report, Rome, Italy.

Hennessy, T., Kinsella, A., 2013, 40 years of Irish farming since joining the European Union: A journey with the Teagasc National Farm Survey 1972-2012. (Teagasc, Ireland).

Hennessy, T., Moran, B., 2015. The Viability of the Irish Farming Sector in 2015. (Teagasc, Carlow, Ireland).

Hennessy, T., Buckley, C., Dillon, E., Donnellan, T., Hanrahan, K., Moran, B., Ryan, M., 2013. Measuring Farm Level Sustainability with the Teagasc National Farm Survey. (Teagasc, Athenry, Co. Galway, Ireland).

Herrera, B., Gerster-Bentaya, M., Knierim, A., 2016. Stakeholders' perceptions of sustainability measurement at farm level. Stud. Agric. Econ. 118, 131-137.

Howley, P., 2015. The happy farmer: the effect of nonpecuniary benefits on behaviour. Am. J. Agric. Econ. 97 (4), 1072-1086.

Jan, P., Dux, D., Lips, M., Alig, M., Dumondel, M., 2012. On the link between economic and environmental performance of Swiss dairy farms of the alpine area. Int. J. Life Cycle Assess. 17, 706-719.

Kahan, D., 2013. Farm Business Analysis Using Benchmarking. Farm Management Extension Guide. Food and Agriculture Organisation (FAO), Rome, Italy.

Kleinhanß, W., Murillo, C., San Juan, C., Sperlich, S., 2007. Efficiency, subsidies, and environmental adaptation of animal farming under CAP. Agric. Econ. 36 (1), 49-65.

Kragten, S., de Snoo, G.R., 2003. Benchmarking farmer performance as an incentive for sustainable farming: environmental impacts of pesticides. Commun. Agric. Appl. Biol. Sci. 68 (4 Pt. B), 727-737.

Läpple, D., Renwick, A., Thorne, F., 2015. Measuring and understanding the drivers of agricultural innovation: evidence from Ireland. Food Policy 51, 1-8.

Latruffe, L., Desjeux, Y., 2016. Common agricultural policy support, technical efficiency and productivity change in French agriculture. Rev. Agric. Food Environ. Rev. 97 (1), $15-28$.

Latruffe, L., Mann, S., 2015. Is part-time farming less subsidised? The example of direct payments in France and Switzerland. Cahiers Agric. 24 (1), 20-27.

Latruffe, L., Piet, L., 2014. Does land fragmentation affect farm performance? A case study from Brittany France. Agric. Syst. 129, 68-80.

Latruffe, L., Diazabakana, A., Bockstaller, C., Desjeux, Y., Finn, J., Kelly, E., Ryan, M., Uthes, S., 2016a. Measurement of sustainability in agriculture: a review of indicators. Stud. Agric. Econ. 118, 123-130.

Latruffe, L., Desjeux, Y., Justinia Hanitravelo, G., Hennessy, T., Bockstaller, C., Dupraz, P., Finn, J., 2016b. Tradeoffs Between Economic, Environmental and Social Sustainability: The Case of a Selection of European Farms. (EU FP7 Research Project FLINT, Deliverable 5.2L).

Lebacq, T., Baret, P.V., Stilmant, D., 2013. Sustainability indicators for livestock farming: a review. Agron. Sustainable Dev. 33, 311-327.

Lobley, M., Butler, A., Reed, M., 2009. The contribution of organic farming to rural development: an exploration of the socio-economic linkages of organic and non-organic farms in England. Land Use Policy 26, 723-735.

Lynch, J., Hennessy, T., Buckley, C., Dillon, E., Donnellan, T., Hanrahan, K., Moran, B., Ryan, M., 2016. Teagasc National Farm Survey 2015 Sustainability Report. (Teagasc, Athenry, Co. Galway, Ireland).

Mollenhorst, H., Berentsen, P.B.M., de Boer, I.J.M., 2006. On-farm quantification of sustainability indicators: an application to egg production systems. Br. Poult. Sci. 47 (4), 405-417.

Moreno-Pires, S., Fidélis, T., 2012. A proposal to explore the role of sustainability indicators in local governance contexts: the case of Palmela, Portugal. Ecol. Indic. 23, 608-615.

Murphy, P., Crosson, P., Schulte, R.P.O., 2013. The carbon navigator: a decision support tool to reduce greenhouse gas emissions from livestock production systems. Animal 7 , 427-436.

O’Donoghue, C., Devisme, S., Ryan, M., Gilepsie, P., Conneely, R., 2016. Farm economic sustainability in the EU - a pilot study. Stud. Agric. Econ. 118 (3), 163-171.

OECD, 2001. Environmental indicators for agriculture. Methods and Results Vol. 3 Organisation for Economic Cooperation and Development (OECD), Paris, France (409p)

Pesti, C., Keszthelyi, S., 2009. Additional Environmental Data in Hungarian FADN Analysis of Crop Farms. Landbouw-Economisch Instituut (LEI), The Netherlands, pp. 86-93 (Report No . 2009-085).
Pretty, J., Sutherland, W.J., Ashby, J., Auburn, J., Baulcombe, D., Bell, M., Bentley, J., Bickersteth, S., Brown, K., Burke, J., Campbell, H., Chen, K., Crowley, E., Crute, I., Dobbelaere, D., Edwards-Jones, G., Funes-Monzote, F., Godfray, H.C.J., Griffon, M., Gypmantisiri, P., Haddad, L., Halavatau, S., Herren, H., Holderness, M., Izac, A.M., Jones, M., Koohafkan, P., Lal, R., Lang, T., McNeely, J., Mueller, A., Nisbett, N., Noble, A., Pingali, P., Pinto, Y., Rabbinge, R., Ravindranath, N.H., Rola, A., Roling, N., Sage, C., Settle, W., Sha, J.M., Shiming, L., Simons, T., Smith, P., Strzepeck, K., Swaine, H., Terry, E., Tomich, T.P., Toulmin, C., Trigo, E., Twomlow, S., Vis, J.K., Wilson, J., Pilgrim, S., 2010. The top 100 questions of importance to the future of global agriculture. Int. J. Agric. Sustain. 8 (4), 219-236.

Roberts, D., Majewski, E., Sulewski, P., 2013. Farm household interactions with local economies: a comparison of two EU case study areas. Land Use Policy 31, 156-165.

Ryan, M., Buckley, C., Dillon, E.J., Donnellan, T., Hanrahan, K., Hennessy, T., Moran, B., 2014. The Development of Farm Level Sustainability Indicators for Ireland using the Teagasc National Farm Survey Paper. In: Paper Presented at the 88th Annual Conference of the Agricultural Economics Society (AES). AgroParisTech, Paris, France.

Ryan, M., Buckley, C., Dillon, E.J., Donnellan, T., Hanrahan, K., Hennessy, T., Moran, B., Kelly, E., 2015. The Most Economically Efficient Farms Produce Lowest GHG Emissions per kg of Product. EuroChoices 14, 26-27.

Ryan, M., Hennessy, T., Buckley, C., Dillon, E.J., Donnellan, T., Hanrahan, K., Moran, B., 2016. Developing farm-level sustainability indicators for Ireland using the Teagasc National Farm Survey. Irish J. Agric. Food 55 (2), 112-125.

Samson, E., van der Werf, H., Dupraz, P., Ruas, J.F., Corson, M., 2012. Estimer les impacts environnementaux des systèmes de production agricole par analyse de cycle de vie avec les données du Réseau d'information comptable agricole (RICA) français. Cahiers Agric. 21 (4), 248-257.

Schaller, N., 1993. The concept of agricultural sustainability Agriculture. Ecosyst. Environ. 46 (1-4), 89-97.

Sheridan, H., McMahon, B.J., Carnus, T., Finn, J.A., Kinsella, A., Purvis, G., 2011. Pastoral farmland habitat diversity in south-east Ireland. Agriculture. Ecosyst. Environ. 144, $130-135$.

Sullivan, A., Finn, J.A., Gormally, M.J., Sheehy Skeffington, M., 2013. Field boundary habitats and their contribution to the area of semi-natural habitats on lowland farms in east Galway, Western Ireland. Biol. Environ. 113 (2), 1-13.

Teillard, F., Maia de Souza, D., Thoma, G., Gerber, P.J., Finn, J.A., 2016. What does lifecycle assessment of agricultural products need for more meaningful inclusion of biodiversity? J. Appl. Ecol. 53, 1422-1429.

Thivierge, M.-N., Parent, D., Bélanger, V., Angers, D.A., Allard, G., Pellerin, D., Vanasse, A., 2014. Environmental sustainability indicators for cash-crop farms in Quebec, Canada: a participatory approach. Ecol. Indic. 45, 677-686.

Thomassen, M.A., Dolman, M.A., van Calker, K.J., de Boer, I.J.M., 2009. Relating life cycle assessment indicators to gross value added for Dutch dairy farms. Ecol. Econ. 68 (8-9), 2278-2284.

Thorne, F.S., Fingleton, W., 2006. Examining the Relative Competitiveness of Milk Production: An Irish Case Study (1996-2004). J. Int. Farm Manag. 3 (4), 1-13.

Uthes, S., Li, F., Kelly, E., 2017. Does EU rural expenditure correspond to regional development needs? Land Use Policy 60, 267-280.

Vilain, L., 1997. A la recherche des indicateurs du développement agricole durable. Travaux et Innovations 43, 52-54.

Vilain, L., 2008. La méthode IDEA: Indicateurs De Durabilité Des Exploitations Agricoles, edition 2008. (Educagri ed. France).

Westbury, D.B., Park, J.R., Mauchline, A.L., Crane, R.T., Mortimer, S.R., 2011. Assessing the environmental performance of UK arable and livestock holdings using data from the Farm Accountancy Data Network (FADN). J. Environ. Manage. 92 (3), 902-909.

Zahm, F., Vaux, P., Vilain, L., Girardin, P., Mouchet, C., 2008. Assessing farm sustainability with the IDEA method - from the concept of agriculture sustainability to case studies on farms. Sustain. Dev. 16 (4), 271-281.

de Koeijer, T.J., Wossink, G.A.A., Struik, P.C., Renkema, J.A., 2002. Measuring agri cultural sustainability in terms of efficiency: the case of Dutch sugar beet growers. J. Environ. Manag. 66 (1), 9-17.

de Olde, E.M., Oudshoorn, F.W., Sørensen, C.A.G., Bokkers, E.A.M., de Boer, I.J.M., 2016 Assessing sustainability at farm-level: lessons learned from a comparison of tools in practice. Ecol. Indic. 66, 391-404.

de Olde, E.M., Moller, H., Marchand, F., McDowell, R.W., MacLeod, C.J., Sautier, M., Halloy, S., Barber, A., Benge, J., Bockstaller, C., Bokkers, E.A.M., de Boer, I.J.M., Legun, K.A., Le Quellec, I., Merfield, C., Oudshoorn, F.W., Reid, J., Schader, C., Szymanski, E., Sørensen, C.A.G., Whitehead, J., Manhire, J., 2017. When experts disagree: the need to rethink indicator selection for assessing sustainability of agriculture. Environ. Dev. Sustain. 19 (4), 1327-1342.

den Biggelaar, C., Suvedi, M., 2000. Farmers' definitions, goals, and bottlenecks of sustainable agriculture in the North-Central Region. Agric. Hum. Values 17, 347-358.

van Calker, K., Berentsen, P., Giesen, G., Huirne, R., 2005. Identifying and ranking attributes that determine sustainability in Dutch dairy farming. Agric. Hum. Values 22 (1), 53-63.

van Passel, S., Nevens, F., Mathijs, E., van Huylenbroeck, G., 2007. Measuring farm sustainability and explaining differences in sustainable efficiency. Ecol. Econ. 62 (1), 149-161.

von Keyserlingk, M.A.G., Rushen, J., de Passillé, A.M., Weary, D.M., 2009. Invited review: the welfare of dairy cattle-Key concepts and the role of science. J. Dairy Sci. 92 4101-4111. 